\title{
БИОЛОГИЗИРОВАННЫЙ КОНТРОЛЬ ОСНОВНЫХ БОЛЕЗНЕЙ АЛЫЧИ ВО ВЛАЖНЫХ СУБТРОПИКАХ КРАСНОДАРСКОГО КРАЯ
}

\author{
Н.Н. ЛЕОНОВ $\bowtie$
}

Для борьбы с фитопатогенами в посадках косточковых культур, в частности алычи (Prunus cerasifera Ehrh.), обычно используют химические фунгициды. Альтернативой им служат биофунгициды - препараты на основе сапротрофных бактерий и грибов. Большинство этих препаратов одновременно подавляют размножение фитопатогенных грибов, снижая инфекционную нагрузку, и индуцируют иммунные реакции растений, повышая их устойчивость к фитопатогенным организмам и другим неблагоприятным факторам внешней среды. В настоящей работе впервые в условиях влажных субтропиков Российской Федерации дана сравнительная оценка эффективности биофунгицидов Бактофит, Витаплан, Гамаир, Фитоспорин-М, использованных совместно с химическими фунгицидами Скор и Хорус в половинной норме расхода, на посадках алычи сорта Обильная. Нашей целью стала разработка систем биологизированной защиты алычи от основных заболеваний (кластероспориоза, монилиоза и серой гнили плодов) на основе применения биопрепаратов совместно со сниженными дозами химических фунгицидов, а также оценка эффективности таких систем и их влияния на урожайность и ежегодный прирост осевых побегов алычи в условиях влажных субтропиков Краснодарского края. Исследования проводили в 2015-2017 годах в посадках алычи сорта Обильная на производственных участках Государственного унитарного предприятия Краснодарского края «Октябрьский» (г. Сочи). Изучена эффективность бактериальных биофунгицидов Бактофит, СП (ООО ПО «Сиббиофарм», Россия), Витаплан, СП (ООО «АгроБиоТехнология», Россия), Гамаир, СП (ООО «АгроБиоТехнология», Россия), Фитоспорин-М, Ж (ООО «НВП «БашИнком», Россия), созданных на основе разных штаммов бактерии Bacillus subtilis, в смеси с половинными нормами препаратов Xорус (Horus ${ }^{\circledR}$, «Syngenta AG», Швейцария) и Скор (Skor®, «Syngenta AG», Швейцария), а также биологического препарата Глиокладин, Ж (ООО «Агробиотехнология», Россия) на основе гриба Trichoderma harzianum без смешивания с Хорусом и Скором. Обработку деревьев проводили посредством опрыскивания растворами фунгицидов два раза за весенний сезон: в фазу набухания почек и в фазу активного роста побегов после цветения. В контроле при обработке использовали воду, в качестве эталона проводили обработку химическими фунгицидами Хорус (1-я обработка) и Скор (2-я обработка). Регулярно оценивали интенсивность развития кластероспориоза, монилиоза и серой гнили плодов и биологическую эффективность использованных препаратов, урожайность и величину годового прироста осевых побегов. По итогам трехлетнего эксперимента максимальную статистически значимую биологическую эффективность в защите алычи от кластероспориоза, серой гнили и бурой монилиальной гнилей показали бактериальный биофунгицид Фитоспорин-М (в сочетании с половинными нормами расхода Хоруса и Скора) и грибной биофунгицид Глиокладин, который применяли без химических фунгицидов. Немного ниже оказалась эффективность Гамаира, но она все же превышала аналогичные показатели эталонной обработки химическими фунгицидами. Эффективность Бактофита в большинстве случаев была ниже, чем в эталоне. Во всех вариантах наименышую эффективность показал Витаплан. Биологическая эффективность всех испытанных препаратов в отношении монилиальной бурой гнили оказалась ниже, чем в случае серой гнили и кластероспориоза. Урожайность алычи при обработке Фитоспорином-М, Глиокладином и Гамаиром была практически одинаковой во всех опытных вариантах (9,8-11,5 т/га), примерно в 1,8-1,9 раза превышая контрольные значения (5,45,7 т/га) и в 1,1-1,2 раза - эталонные (8,9-9,1 т/га). При использовании Бактофита урожайность алычи была почти равна эталонной (8,7-9,4 т/га), при обработке Витапланом - регулярно ниже эталонной (6-7 т/га). Показатели сохраненного урожая в вариантах применения биологических препаратов достигали 9,7-11,5 т/га. Увеличение прироста осевых побегов алычи по сравнению с контролем оказалось максимальным (в 1,7 раза) при применении Глиокладина и немного меньшим - при использовании Фитоспорина-М и Гамаира, тогда как при применении Бактофита и Витаплана оно было ниже эталонных значений на 15-25 \%, только в 1,1-1,2 раза превышая контроль. Таким образом, биологические средства защиты растений на основе Bacillus subtilis и Trichoderma harzianum могут успешно применяться против основных болезней алычи в субтропиках Краснодарского края. Допустимо применение бактериальных препаратов в смеси с уменьшенными нормами расходов химических фунгицидов, что позволило бы сокращать объемы используемых химических пестицидов и экономить средства на проведение защитных мероприятий.

Ключевые слова: биологическая защита растений, биофунгициды, фитопатогенные грибы, косточковые культуры, биологическая эффективность, Bacillus subtilis, Trichoderma harzianum. 
Природно-климатические условия субтропиков Краснодарского края позволяют получать высокие урожаи косточковых культур, в частности алычи (Prunus cerasifera Ehrh.). Однако они же благоприятствуют интенсивному развитию целого ряда вредоносных фитопатогенных грибов (1). К наиболее значимым возбудителям болезней косточковых культур в условиях Сочи относятся Monilinia fructigena (Pers.) Honey и M. laxa (Aderh. \& Ruhland) Honey, а также недавно обнаруженный инвазивный вид $M$. fructicola (G. Winter) Honey (2), которые вызывают монилиозы - специфические плодовые гнили и ожоги цветков и молодых побегов алычи. Важное значение имеют Botrytis cinerea Pers. - возбудитель серой гнили и Wilsonomyces carpophilus (Lev.) Adask., J.M. Ogawa \& E.E. Butler (=Clasterosporium carpophilum (Lev.) Aderh., =Stigmina carpophila (Lev.) М.В. Ellis) - возбудитель кластероспориоза, комплексного заболевания косточковых культур, проявляющегося в отмирании побегов, повреждении плодов и дырчатой пятнистости листьев (3).

Для борьбы с перечисленными фитопатогенами алычи обычно используют химические фунгициды $(4,5)$, несмотря на негативные последствия их применения - токсичность, неизбирательность действия и риск появления устойчивости у фитопатогенов (6). Альтернативой химическим фунгицидам служат биофунгициды - препараты на основе сапротрофных бактерий и грибов $(7,8)$. В настоящее время их применение уже стало одним из наиболее перспективных направлений в защите сельскохозяйственных культур $(9,10)$. Большинство этих препаратов одновременно подавляют размножение фитопатогенных грибов, снижая инфекционную нагрузку, и индуцируют иммунные реакции растений, повышая их устойчивость к фитопатогенным организмам и другим неблагоприятным факторам внешней среды $(11,12)$. В последние годы в России производятся биофунгициды на основе высокоэффективных штаммов бактерии Bacillus subtilis и гриба Trichoderma harzianum, известных как естественные антагонисты фитопатогенных грибов и индукторы иммунного ответа растений (13-15). Такие препараты все чаще используются для защиты растений, поскольку способны подавлять разнообразные фитопатогены и характеризуются высокой экологической безопасностью (16-20). Однако до сих пор имеются только единичные исследования, посвященные их применению для защиты косточковых культур в России $(21,22)$.

В настоящей работе впервые в условиях влажных субтропиков Российской Федерации дана сравнительная оценка эффективности биофунгицидов Бактофит, Витаплан, Гамаир, Фитоспорин-М, использованных совместно с химическими фунгицидами Скор и Хорус в половинной норме расхода, на посадках алычи сорта Обильная.

Нашей целью стала разработка систем биологизированной защиты алычи от основных заболеваний (кластероспориоза, монилиоза и серой гнили плодов) на основе применения биопрепаратов совместно со сниженными дозами химических фунгицидов, а также оценка эффективности таких систем, их влияния на урожайность и ежегодный прирост осевых побегов алычи в условиях влажных субтропиков Краснодарского края.

Методика. Исследования проводили в 2015-2017 годах в посадках алычи сорта Обильная на производственных участках Государственного унитарного предприятия Краснодарского края «Октябрьский» (г. Сочи), расположенных на расстоянии 5 км от побережья Черного моря. Деревья обрабатывали готовыми растворами фунгицидов.

Использовали химические фунгициды - Хорус (Horus®, ВДГ, 750 г/л, 0,3 кг/га, «Syngenta AG», Швейцария) и Скор (Skor®), КЭ, 250 г/л, 0,2 л/га, 
«Syngenta AG», Швейцария); бактериальные биофунгициды на основе бактерии Bacillus subtilis - Бактофит, СП (штамм ИПМ 215 БА-10000 ЕД/г, титр не менее 2 млрд спор/г; ООО ПО «Сиббиофарм», Россия), Витаплан, СП (штамм ВКМ-B-2604D, титр не менее $10^{10} \mathrm{KOE} / г$; ООО «АгроБиоТехнология», Россия), Гамаир, СП (штамм М-22 ВИЗР, титр не менее $10^{11} \mathrm{KOE} / г$; ООО «АгроБиоТехнология», Россия), Фитоспорин-М, Ж (штамм 26 Д, титр не менее 1 млрд живых клеток и спор/м; ООО «НВП «БашИнком», Россия); грибной биофунгицид на основе гриба Trichoderma harzianum Глиокладин, Ж (штамм 18 ВИЗР, титр не менее $10^{9} \mathrm{KOE} / \mathrm{Mл}$; ООО «Агробиотехнология», Россия).

Схема опыта была следующей: контроль - опрыскивание водой (2 обработки); эталон - Хорус, 0,3 кг/га (1-я обработка), Скор, 0,2 л/га (2-я обработка); вариант 1 - Бактофит, 2 кг/га + Хорус, 0,15 кг/га (1-я обработка), Бактофит, 2 кг/га + Скор, 0,1 л/га (2-я обработка); вариант 2 - Витаплан, 0,12 кг/га + Хорус, 0,15 кг/га (1-я обработка), Витаплан, 0,12 кг/га + Скор, 0,1 л/га (2-я обработка); вариант 3 - Гамаир, 0,15 кг/га + Хорус, 0,15 кг/га (1-я обработка), Гамаир, 0,15 кг/га + Скор, 0,1 л/га (2-я обработка); вариант 4 - Фитоспорин-М, 2 л/га + Хорус, 0,15 л/га (1-я обработка), Фитоспорин-М, 2 л/га + Скор, КЭ, 0,1 л/га (2-я обработка); вариант 5 - Глиокладин, 3 л/га (2 обработки).

Поскольку бактериальные препараты достаточно хорошо совместимы с химическими фунгицидами $(1,21,22)$, они применялись в виде баковых смесей с половинными нормами расхода химических фунгицидов (Хорус - при 1-й обработке, Скор - при 2-й обработке).

Контроль, эталон и каждый вариант опыта были заложены в 4-кратной повторности при рандомизированном размещении делянок площадью 20 м $^{2}$ каждая (23). Первую обработку проводили в фазу набухания почек, вторую - после цветения в фазу активного роста и развития побегов и листьев. Даты обработок биопрепаратами смещались на срок от 2 до 11 сут в зависимости от погодных условий каждого года. Опрыскивание растворами проводили в утренние часы при температуре воздуха не выше $+24{ }^{\circ} \mathrm{C}$. Поскольку действие биофунгицидов носит длительный характер (24), интенсивность развития кластероспориоза во всех вариантах опыта оценивали через 10 сут после каждой обработки, а серой и бурой гнилей плодов - через 1 мес после прекращения обработок.

Степень развития кластероспориоза, монилиоза и серой гнили плодов подсчитывали по общепринятой методике (23). Интенсивность развития болезни оценивали по 5-балльной шкале со следующими градациями: 0 - отсутствие поражения, 1 - поражено до $10 \%$ поверхности листа, 2 поражено 11-25 \% поверхности, 3 - поражено 26-50 \% поверхности, 4 поражено свыше 50 \% поверхности.

Показатель развития болезни, отражающий относительную степень поражения каждой делянки (варианта опыта), вычисляли по формуле W.S. Abbott (25):

$$
\mathrm{R}=\frac{\Sigma(\mathrm{a} \cdot \mathrm{b})}{\mathrm{N} \cdot \mathrm{K}}
$$

где $\mathrm{R}$ - развитие болезни, \%, $\Sigma(\mathrm{a} \cdot \mathrm{b})$ - сумма произведений числа больных листьев (a) на соответствующий им балл поражения (b), N - общее число учтенных листьев (здоровых и больных), шт., К - высший балл шкалы учета.

Биологическую эффективность (БЭ) рассчитывали по формуле:

$$
\mathrm{BE}=\frac{\mathrm{K}-\mathrm{b}}{\mathrm{K}},
$$


где ВЕ - биологическая эффективность, \%, K - интенсивность развития болезни в контроле, $\mathrm{b}$ - интенсивность развития болезни в варианте опыта.

Для более полной оценки схем защиты алычи определяли урожайность (измерялась во время сбора урожая) и прирост побегов за вегетационный сезон (измерялся по окончании вегетации).

Полученные данные обрабатывали методами описательной статистики в программах Microsoft Excel и Statistica 10 («StatSoft, Inc.», США) (26). Вычисляли средние арифметические значения $(M)$ и стандартные ошибки средних $( \pm \mathrm{SEM})$. Для сравнения нескольких независимых групп данных (варианты опыта), объединенных по одному признаку (варианты обработки) использовали одномерный однофакторный анализ (23). При оценке соотношения межгрупповой изменчивости применяли критерий Фишера ( $F$-test) для проверки нулевой гипотезы о равенстве средних для выборок вариантов опыта, для уровня значимости $\mathrm{p}<0,05$ (23). Вычисляли наименьшую существенную разность $\left(\mathrm{HCP}_{05}\right)$ - величину, указывающую границу возможных случайных отклонений в эксперименте, то есть минимальную разность между средними значениями степени развития болезни и урожая для каждого варианта опыта и контроля.

Результаты. Погодные условия весенних и летних месяцев 20152017 годов в Сочи не отличались существенными отклонениями от климатической нормы (27) и способствовали интенсивному развитию основных болезней алычи. Максимальная степень развития кластероспориоза и плодовых гнилей отмечалась в 2015 году (табл. 1), чему способствовала высокая влажность воздуха и раннее наступление весны. Полученные результаты свидетельствуют о довольно высокой эффективности биофунгицидов (59,84-96,8 \%) в защите алычи от кластероспориоза (табл. 1).

1. Интенсивность развития кластероспориоза (\%) и биологическая эффективность (\%) различных схем защиты алычи (Prunus cerasifera Ehrh.) сорта Обильная $(N=4, M \pm \mathrm{SEM}$, Государственное унитарное предприятие Краснодарского края «Октябрьский», г. Сочи)

\begin{tabular}{|c|c|c|c|c|c|c|}
\hline \multirow{2}{*}{ Вариант } & \multicolumn{2}{|c|}{2015 год } & \multicolumn{2}{|c|}{2016 год } & \multicolumn{2}{|c|}{2017 год } \\
\hline & ИР & БЭ & ИР & БЭ & ИР & БЭ \\
\hline 1 & $6,1 \pm 0,15$ & $74,9 \pm 0,91$ & $4,5 \pm 0,91$ & $77,1 \pm 1,64$ & $2,5 \pm 0,22$ & $79,7 \pm 2,67$ \\
\hline 2 & $9,6 \pm 0,21$ & $60,1 \pm 1,39$ & $7,8 \pm 0,31$ & $59,8 \pm 4,00$ & $4,6 \pm 0,14$ & $63,2 \pm 1,71$ \\
\hline 3 & $4,2 \pm 0,23$ & $82,6 \pm 1,02$ & $2,9 \pm 0,21$ & $85,0 \pm 1,73$ & $1,5 \pm 0,08$ & $88,0 \pm 0,93$ \\
\hline 5 & $2,6 \pm 0,21$ & $89,2 \pm 1,02$ & $1,6 \pm 0,08$ & $92,0 \pm 0,40$ & $0,8 \pm 0,13$ & $93,6 \pm 1,22$ \\
\hline 4 & $1,7 \pm 0,18$ & $93,0 \pm 0,65$ & $0,8 \pm 0,13$ & $95,9 \pm 0,54$ & $0,4 \pm 0,06$ & $96,8 \pm 0,43$ \\
\hline Эталон & $4,4 \pm 0,21$ & $81,8 \pm 0,90$ & $3,1 \pm 0,26$ & $84,2 \pm 2,48$ & $1,6 \pm 0,23$ & $97,0 \pm 2,27$ \\
\hline Контроль & $24,1 \pm 0,49$ & & $20,0 \pm 1,98$ & & $12,6 \pm 0,77$ & \\
\hline $\mathrm{HCP} 05$ & 0,56 & 2,99 & 0,27 & 8,40 & 0,96 & 5,12 \\
\hline & $\begin{array}{c}F_{\Phi}=1611,3> \\
>F_{\mathrm{T}}=2,57\end{array}$ & $\begin{array}{c}F_{\phi}=134,82> \\
>F_{\mathrm{T}}=2,77\end{array}$ & $\begin{array}{c}F_{\Phi}=74,09> \\
>F_{\mathrm{T}}=2,57\end{array}$ & $\begin{array}{c}F_{\Phi}=20,92> \\
>F_{\mathrm{T}}=2,77\end{array}$ & $\begin{array}{c}F_{\Phi}=172,24> \\
>F_{\mathrm{T}}=2,57\end{array}$ & $\begin{array}{c}F_{\Phi}=49,04> \\
>F_{\mathrm{T}}=2,77\end{array}$ \\
\hline
\end{tabular}

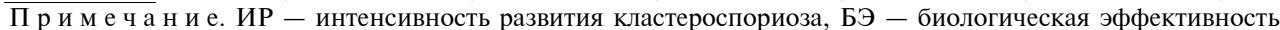
в защите от кластероспориоза. Описание вариантов см. в разделе «Методика». Различия статистически значимы $\left(F_{\Phi}>F_{\mathrm{T}}\right)$ на уровне $95 \%$.

За 3-летний период наилучший результат в защите алычи от кластероспориоза показал бактериальный биофунгицид Фитоспорин-М, на втором месте оказался грибной биофунгицид Глиокладин (см. табл. 1), однако следует учесть, что он применялся без смеси с химическими фунгицидами. При этом БЭ при обработке смесями бактериальных биофунгицидов Фитоспорин-М и Гамаир с половинными нормами расхода химических фунгицидов, как и применение Глиокладина в чистом виде, давало лучший эффект, чем обработка полной нормой химических фунгицидов в эталоне (табл. 2). Даже при наивысшей степени развития кластероспориоза в июне 2015 года интенсивность развития болезни после применения ФитоспоринаМ, Глиокладина и Гамаира была не выше, чем при эталонной обработке 
только химическими фунгицидами, тогда как Бактофит и Витаплан несколько уступали им по эффективности.

При применении Глиокладина даже через 1 мес после прекращения обработок интенсивность развития кластероспориоза была ниже, чем на деревьях, обработанных только химическими фунгицидами. Это свидетельствует о пролонгированном защитном эффекте грибного биофунгицида, который обусловлен не только подавлением возбудителя кластероспориоза, но и активацией защитных механизмов растения (28).

Аналогичные результаты в условиях Сочи были зафиксированы на сливе сорта Стенлей: лучший эффект защиты от кластероспориоза также достигался при использовании Фитоспорина-М и Глиокладина (1). Близкие результаты получены при испытании биопрепаратов на основе B. subtilis и T. lignorum в предгорной зоне Краснодарского края для защиты сливы от кластероспориоза, хотя в последнем случае первая обработка до распускания почек проводилась только химическими фунгицидами, а после цветения применялись лишь биопрепараты в чистом виде (22).

Биофунгициды показали хороший результат и в борьбе против серой и монилиальной бурой плодовой гнилей: степень развития плодовых гнилей достоверно $(\mathrm{p}<0,05)$ существенно снижалась по сравнению с контролем (табл. 2), хотя БЭ всех препаратов в отношении монилиальной бурой гнили оказалась ниже, чем в отношении кластероспориоза (см. табл. 1) и серой гнили (табл. 3).

2. Биологическая эффективность (\%) различных схем защиты алычи (Prunus cerasifera Ehrh.) сорта Обильная от монилиальной бурой гнили $(N=4, M \pm \mathrm{SEM}$, Государственное унитарное предприятие Краснодарского края «Октябрьский», г. Сочи)

\begin{tabular}{l|c|c|c}
\hline Вариант & 2015 год & 2016 год & 2017 год \\
\hline 1 & $62,2 \pm 3,03$ & $68,5 \pm 2,69$ & $71,6 \pm 3,74$ \\
2 & $55,4 \pm 1,79$ & $46,0 \pm 2,28$ & $56,6 \pm 3,24$ \\
3 & $75,7 \pm 2,54$ & $77,9 \pm 2,74$ & $81,0 \pm 2,24$ \\
5 & $76,5 \pm 2,65$ & $78,8 \pm 3,01$ & $85,0 \pm 2,41$ \\
4 & $80,1 \pm 3,23$ & $82,8 \pm 4,53$ & $87,1 \pm 3,14$ \\
Эталон & $69,9 \pm 2,55$ & $72,2 \pm 3,25$ & $80,3 \pm 3,32$ \\
$\quad$ НСР05 & 9,73 & 7,83 & 7,01 \\
\multicolumn{2}{c|}{$F_{\phi}=11,06>F_{\mathrm{T}}=2,77$} & $F_{\phi}=29,80>F_{\mathrm{T}}=2,77$ & $F_{\Phi}=23,04>F_{\mathrm{T}}=2,77$
\end{tabular}

П и м еч а и е. Описание вариантов см. в разделе «Методика». Различия статистически значимы $\left(F_{\phi}>F_{\mathrm{T}}\right)$ на уровне $95 \%$.

3. Биологическая эффективность (\%) различных схем защиты алычи (Prunus cerasifera Ehrh.) сорта Обильная от серой гнили ( $N=4, M \pm \mathrm{SEM}$, Государственное унитарное предприятие Краснодарского края «Октябрьский», г. Сочи)

\begin{tabular}{l|c|c|c}
\hline \multicolumn{1}{c|}{ Вариант } & 2015 год & 2016 год & 2017 год \\
\hline 1 & $67,6 \pm 2,60$ & $74,5 \pm 3,23$ & $77,8 \pm 2,35$ \\
2 & $58,4 \pm 2,74$ & $51,1 \pm 1,64$ & $87,5 \pm 2,55$ \\
3 & $82,3 \pm 3,85$ & $84,7 \pm 1,97$ & $88,5 \pm 3,11$ \\
5 & $83,1 \pm 4,19$ & $85,7 \pm 1,78$ & $92,4 \pm 1,71$ \\
4 & $87,1 \pm 13,4$ & $90,0 \pm 2,56$ & $87,3 \pm 1,78$ \\
Эталон & $76,0 \pm 2,77$ & $78,5 \pm 3,86$ & 7,01 \\
НСР05 & 9,73 & 7,83 & $F_{\phi}=23,04>F_{\mathrm{T}}=2,77$ \\
\multicolumn{2}{l}{ Пр и м е ч а н и е. Описание вариантов см. в разделе «Методика». Различия статистически значимы } \\
$\left(F_{\phi}>F_{\mathrm{T}}\right)$ на уровне 95 \%.
\end{tabular}

Как и в случае кластероспориоза, все испытанные биопрепараты показали достаточно высокую биологическую эффективность по итогам трехлетнего эксперимента, при этом у Фитоспорина-М, Глиоклалина и Гамаира она превышала наблюдаемую в эталоне по меньшей мере в 1,1- 
1,2 раза (p < 0,05) (см. табл. 2 и 3). Максимальный эффект наблюдался при применении Фитоспорина-М в баковой смеси с химическими фунгицидами, а Глиокладин и Гамаир немного уступали ему по эффективности. Наименьшую эффективность при защите алычи от плодовых гнилей по сравнению с другими биофунгицидами показали Бактофит и Витаплан: для обоих биопрепаратов БЭ всегда была ниже по сравнению с эталоном на 20$40 \%$ (см. табл. 2 и 3).

Наилучший результат в борьбе с серой гнилью был получен при использовании половинных норм расхода Хоруса и Скора в сочетании с Фитоспорином-М (87,1-92,4 \%). Биологическую эффективность выше эталона показали биофунгициды Глиокладин и Гамаир, особенно по сравнению с Витапланом, который и здесь имел наименьшую эффективность.

Урожайность алычи в целом отражала степень защитного действия каждого испытанного препарата: наивысшей она оказалась при использовании биопрепарата Фитоспорин-М, однако Глиокладин и Гамаир уступали здесь ему незначительно. Так, в 2015 году самая высокая урожайность наблюдалась у деревьев, обработанных Гамаиром (табл. 4).

4. Урожайность (т/га) алычи (Prunus cerasifera Ehrh.) сорта Обильная в зависимости от различных схем обработки посевов биофунгицидами $(N=4, M \pm \mathrm{SEM}$, Государственное унитарное предприятие Краснодарского края «Октябрьский», г. Сочи)

\begin{tabular}{|c|c|c|c|}
\hline Вариант & 2015 год & 2016 год & 2017 год \\
\hline 1 & $8,7 \pm 0,55$ & $9,2 \pm 0,23$ & $9,4 \pm 0,18$ \\
\hline 2 & $7,0 \pm 0,25$ & $6,6 \pm 0,27$ & $6,0 \pm 0,29$ \\
\hline 3 & $9,8 \pm 0,35$ & $10,0 \pm 0,25$ & $10,2 \pm 0,33$ \\
\hline 5 & $9,7 \pm 0,13$ & $10,9 \pm 0,35$ & $11,5 \pm 0,20$ \\
\hline 4 & $9,7 \pm 0,30$ & $10,5 \pm 0,30$ & $11,0 \pm 0,35$ \\
\hline Эталон & $8,9 \pm 0,29$ & $9,1 \pm 0,27$ & $9,0 \pm 0,27$ \\
\hline Контроль & $5,4 \pm 0,26$ & $5,7 \pm 0,27$ & $5,6 \pm 0,24$ \\
\hline \multirow[t]{2}{*}{$\mathrm{HCP} 05$} & 0,96 & 0,82 & 0,81 \\
\hline & $F_{\Phi}=26,02>F_{\mathrm{T}}=2,57$ & $F_{\phi}=49,82>F_{\mathrm{T}}=2,57$ & $F_{\phi}=71,77>F_{\mathrm{T}}=2,57$ \\
\hline $\begin{array}{l}\text { Пр и ме ча н } \\
\left(F_{\phi}>F_{T}\right) \text { на уро }\end{array}$ & ание вариантов см. в & еле «Методика». Различия & статистически значимы \\
\hline
\end{tabular}

При этом из-за интенсивного развития фитопатогенных грибов урожайность алычи в контроле была значительно (в 1,3-2 раза, p < 0,05) ниже, чем во всех опытных вариантах (см. табл. 4), а показатели сохраненного урожая в вариантах применения биологических препаратов достигали 9,711,5 т/га. В вариантах с использованием Фитоспорина-М, Гамаира и Глиокладина урожайность превосходила показатель в эталоне в 1,7-1,9 раза $(\mathrm{p}<0,05)$, в варианте с Бактофитом результаты были почти одинаковыми, а при использовании Витаплана урожайность алычи была ниже, чем в эталоне, однако в 1,1-1,3 раза выше аналогичных значений в контроле (табл. 4).

Известно, что урожайность алычи существенно зависит от интенсивности развития однолетних побегов в течение вегетационного сезона, а изучаемые болезни, особенно кластероспориоз, угнетают прирост побегов (1). Следовательно, величина годового прироста побегов может рассматриваться как важный показатель для оценки и защитного, и ростостимулирующего действия испытанных средств защиты. По итогам измерений длины осевых побегов текущего года в осенний сезон после завершения роста (табл. 5) биофунгициды Фитоспорин-М, Гамаир и особенно Глиокладин в опытных вариантах показали лучшие результаты, чем химические фунгициды в эталоне: применение биопрепаратов приводило к увеличению средней длины побегов текущего года по сравнению с контролем в 1,2-1,7 раза $(\mathrm{p}<0,05)$ (см. табл. 5). 
5. Прирост побегов (см/год) алычи (Prunus cerasifera Ehrh.) сорта Обильная в зависимости от различных схем обработки посевов биофунгицидами $(N=4$, $M \pm \mathrm{SEM}$, Государственное унитарное предприятие Краснодарского края «Октябрьский», г. Сочи)

\begin{tabular}{l|c|c|c}
\hline \multicolumn{1}{c|}{ Вариант } & 2015 год & 2016 год & 2017 год \\
\hline 1 & $62,2 \pm 3,00$ & $67,6 \pm 2,60$ & $74,9 \pm 0,90$ \\
2 & $55,4 \pm 1,80$ & $58,4 \pm 2,70$ & $60,1 \pm 1,40$ \\
3 & $75,7 \pm 2,50$ & $82,3 \pm 3,90$ & $82,6 \pm 1,00$ \\
5 & $76,5 \pm 2,70$ & $83,1 \pm 4,20$ & $89,2 \pm 1,00$ \\
4 & $80,1 \pm 3,20$ & $87,1 \pm 13,40$ & $93,0 \pm 0,70$ \\
Эталон & $69,9 \pm 2,60$ & $76,0 \pm 2,80$ & $81,7 \pm 0,90$ \\
Контроль & $45,9 \pm 2,30$ & $51,1 \pm 1,60$ & $55,4 \pm 1,80$ \\
НСР05 & 0,27 & 0,56 & 0,82 \\
& $F \Phi=74,09>F_{\mathrm{T}}=2,57$ & $F_{\phi}=1611,3>F_{\mathrm{T}}=2,57$ & $F_{\phi}=49,82>F_{\mathrm{T}}=2,57$
\end{tabular}

Пр и меч а н ие. Описание вариантов см. в разделе «Методика». Различия статистически значимы $\left(F_{\phi}>F_{\mathrm{T}}\right)$ на уровне $95 \%$.

Особенно следует отметить эффект Глиокладина, при использовании которого прирост побегов алычи был максимален по итогам всех трех лет эксперимента: длина однолетних побегов примерно в 1,7 раза превышала длину аналогичных побегов в контроле $(\mathrm{p}<0,05)$. Лучшие результаты показал Фитоспорин-М, хотя значения длины побегов были близки к таковым при применении Глиокладина. По нашему мнению, такие результаты можно объяснить тем, что этот грибной биопрепарат обладает не только выраженным иммуномодулирующим, но ростостимулирующим эффектом (29). В опытных вариантах с Бактофитом и Витапланом прирост превышал контрольные значения только в 1,1-1,2 раза и был ниже эталонных значений на 15-25 \%, тогда как обработка одними химическими препаратами в эталоне давала среднее увеличение прироста в 1,5 раза по сравнению с контролем.

Таким образом, биофунгициды Бактофит, Витаплан, Гамаир, Фитоспорин-М на основе Bacillus subtilis и Trichoderma harzianum могут успешно применяться против основных болезней алычи в субтропиках Краснодарского края в смесях с половинными нормами химических фунгицидов. Проведенные исследования позволяют судить о высокой эффективности биологических препаратов. В 2015-2017 годах наибольшая эффективность от кластероспориоза составила 93-97 \%, от монилиоза - 80-87 \%, от серой гнили - 87-92\%. Наивысшая урожайность алычи в эти годы составила 9,8-11,5 т/га, величина годового прироста побегов деревьев алычи достигала 80-93 см.

ФГБУН ФИЦ Субтропический научный центр РАН,

Поступила в редакцию 354002 Россия, г. Сочи, ул. Яна Фабрициуса, 2/28, 22 сентября 2021 года

\title{
BIOLOGIZED CONTROL OF THE MAIN DISEASES OF CHERRY PLUM IN HUMID SUBTROPICS OF THE KRASNODAR REGION
}

\author{
N.N. Leonov
}

Federal Research Centre the Subtropical Scientific Centre RAS, 2/28, ul. Yana Fabriciusa, Sochi, 354002 Russia, email ozr@vniisubtrop.ru ( $\square$ corresponding author)

ORCID:

Leonov N.N. orcid.org/0000-0002-1312-7487

The author declares no conflict of interests

Received September 22, 2021

doi: 10.15389/agrobiology.2021.5.990eng 


\section{Abstract}

Chemical fungicides are usually used to combat phytopathogens in stone fruit crops, in particular cherry plum (Prunus cerasifera Ehrh.). Biofungicides are an alternative to chemicals. Biofungicides preparations are based on saprotrophic bacteria and fungi. Most of these drugs suppress the reproduction of fungal plant pathogens thus reducing the infectious load. These drugs induce immune responses in plants, increasing their resistance to pathogens and unfavorable environmental factors. In this work, for the first time in humid subtropics, we have given a comparative assessment of the biological effectiveness of the biofungicides Baktofit, Vitaplan, Gamair, Fitosporin-M, used together with the chemical fungicides Skor and Horus at half the rate of application. Our goal was to develop systems of biologic protection of cherry plum from the main diseases (clusterosporium disease, moniliosis, and gray rot of fruits) based on biological products in combination with reduced doses of chemical fungicides in conditions humid subtropics of the Krasnodar Territory. The work also aimed to assess the effect of such systems on the yield and annual growth of axial shoots of cherry plum. The research was carried out in 2015-2017 in plantings of cherry plum variety Obilnaya at the production sites of the State Unitary Enterprise of the Krasnodar Territory "Oktyabrsky" (Sochi). We compared the effect of various Bacillus subtilis bacteria-based fungicides, namely Baktofit, SP (Sibbiopharm, Russia), Vitaplan (AgroBioTechnology, Russia), SP, Gamair, SP (AgroBioTechnology, Russia), and Fitosporin-M, Zh (BashInkom, Russia) in mixes with half the norms of Horus (Horus ${ }^{\circledR}$, Syngenta AG, Switzerland) and Skor (Skor ${ }^{\circledR}$, Syngenta AG, Switzerland), as well as the Trichoderma harzianum-based preparation Glyokladin, Zh (Agrobiotekhnologiya, Russia) without mixing with Horus and Skor. Trees were sprayed with fungicide solutions twice during the spring season, in the bud-swelling phase and in the phase of active shoot growth after flowering. The water was control during the treatment. The chemical fungicides Horus (1st treatment) and Skor (2nd treatment) were as a reference. The intensity of the development of clusterosporiosis, monilioz and gray rot of fruits and the biological effectiveness of the preparations used, the yield and the value of the annual growth of axial shoots were assessed. According to a three-year experiment, the bacterial biofungicide Fitosporin- $\mathrm{M}$ in combination with half the consumption rates of Horus and Skor and the fungal biofungicide Glyocladin without chemical fungicides showed the maximum statistically significant biological effectiveness in protecting cherry plum from clusterosporia, gray rot and brown monilial rot. The efficiency of Gamair turned out to be slightly lower, but it still exceeded the indicators of the reference treatment with chemical fungicides. The efficiency of Baktofit in most cases was lower than the reference. Vitaplan showed the lowest efficiency in all variants. The biological effectiveness of all tested preparations against monilial brown rot was lower than in the case of gray rot and clusterosporiosis. The yield of cherry plum when treated with Fitosporin-M, Glyokladin and Gamair was practically the same in all tests $(9.8-11.5 \mathrm{t} / \mathrm{ha})$, being approximately $1.8-1.9$ times higher than the control values (5.4-5.7 t/ha) and 1.1-1.2 times higher than the reference (8.9-9.1 t/ha). When using Baktofit, the yield of cherry plum was almost equal to the reference (8.7-9.4 t/ha), while when treated with Vitaplan it was regularly below the reference $(6-7 \mathrm{t} / \mathrm{ha})$. The preserved yield upon treatment with biological preparations reached 9.7-11.5 t/ha. The increase in the growth of the axial shoots of cherry plum compared to the control turned out to be maximum (1.7 times) for Glyokladin and slightly less for Fitosporin-M and Gamair, while when using Baktofit and Vitaplan it was 15$25 \%$ lower than the reference values and only 1.1-1.2 times higher than the control values. Thus, biological plant protection products based on Bacillus subtilis and Trichoderma harzianum can be successful against the main diseases of cherry plum in the subtropics of Krasnodar Territory. It is acceptable to use bacterial preparations in a mixture with lower rates of chemical fungicides. This approach is more environmentally friendly and reduces the cost of plant protection.

Keywords: biological plant protection, biofungicides, fungal plant pathogens, stone fruit crops, biological effectiveness, Bacillus subtilis, Trichoderma harzianum.

\section{REFEREN C ES}

1. Leonov N., Bulgakov T. Biological protection of plum from shot hole disease in the humid subtropics of the Krasnodar region (Russia). BIO Web Conferences, 2020, 21: 00035 (doi: 10.1051/bioconf/20202100035).

2. Mikhailova E.V., Karpun N.N., Pantiya G.G. Plodovodstvo i yagodovodstvo Rossii, 2020, 60(1): 186-191 (doi: 10.31676/2073-4948-2020-60-186-191) (in Russ.).

3. Ahmadpour A. Review of shot-hole disease of stone-fruit trees. Plant Pathology Science, 2017, 7(2): 1-13 (doi: 10.29252/pps.7.2.1).

4. Karpun N.N., Ignatova E.A., Yanushevskaya E.B., Leonov N.N. Evolution of chemical methods of plant protection from pests in Russian humid subtropics and the problem of ecological safety. Sel'skokhozyaistvennaya biologiya [Agricultural Biology], 2014, 3: 32-39.

5. Pesticides in the modern world - pesticides use and management. M. Stoytcheva (ed.). In Tech, Croatia, 2011: 520. 
6. Mironova M.K., Izhevskii S.S., Akhatov A.K. Zashchita i karantin rastenii, 2006, 5: 80 (in Russ.).

7. Falardeau J., Wise C., Novitsky L., Avis T.J. Ecologisal and mechanistic insights into the direct and indirect antimicrobial properties of Bacillus subtilis lipopeptides on plant pathogens. J. Chem. Ecol., 2013, 39(7): 869-878 (doi: 10.1007/s10886-013-0319-7).

8. Adnan M., Islam W., Shabbir A., Khan K.A., Ghramh H.A., Huang Z., Chen H.Y.H., Lu G.D. Plant defense against fungal pathogens by antagonistic fungi with Trichoderma in focus. Microbial Pathogenesis, 2019, 129: 7-18 (doi: 10.1016/j.micpath.2019.01.042).

9. Olson S. An analysis of the biopesticide market now and where it is going. Outlooks on Pest Management, 2015, 26(5): 203-206 (doi: 10.1564/v26_oct_04).

10. Lord J.C. From Metchnikoff to Monsanto and beyond: The path of microbial control. Journal of Invertebrate Pathology, 2005, 89 (1): 19-29 (doi: 10.1016/j.jip.2005.04.006).

11. Induced resistance for plant defence: a sustainable approach to crop protection. D. Waltrs, A. Newton, G. Lyon (eds.). Blackwell Publishing, Oxford, 2007: 258.

12. Gouda S., Kerry R.C., Das G., Paramithiotis S., Shin H.-S., Patra J.K. Revitalization of plant growth promoting rhizobacteria for sustainable development in agriculture. Microbiological Research, 2018, 206: 131-140 (doi: 10.1016/j.micres.2017.08.016).

13. Peréz-García A., Romero D., Vicente de A. Plant protection and growth stimulation by microorganisms: biotechnological applications of Bacilli in agriculture. Current Opinion in Biotechnology, 2011, 22(2): 187-193 (doi: 10.1016/j.copbio.2010.12.003).

14. Mastouri F., Bjorkman T., Harman G. Seed treatments with Trichoderma harzianum alleviate biotic, abiotic and physiological stresses in germinating seeds and seedlings. Journal of Phytopathology, 2010, 100(11): 1213-1221 (doi: 10.1094/PHYTO-03-10-0091).

15. Caulier S., Nannan C., Gillis A., Licciardi F., Bragard C., Mahillon J. Overview of the antimicrobial compounds produced by members of the Bacillus subtilis group. Front. Microbial, 2019, 10: 302 (doi: 10.3389/fmicb.2019.00302).

16. Strasser H., Kirchmair M. Potential health problems due to exposure in handling and using biological control agents. In: An ecological and societal approach to biological control. Progress in Biological Control, vol. 2. J. Eilenberg, H.M.T. Hokkanen (eds.). Springer, Dordrecht, 2006: 275293 (doi: 10.1007/978-1-4020-4401-4_14).

17. Kumar D., Singh M.K., Singh H.K., Singh K.N. Fungal biopesticides and their uses for control of insect pest and diseases. In: Biofertilizers and biopesticides in sustainable agriculture. Apple Academic Press, 2019: 43-70.

18. Hashem A., Tabassum B., Abd_Allah E.F. Bacillus subtilis: a plant-growth promoting rhizobacterium that also impact biotic stress. Saudi Journal of Biological Sciences, 2019, 26(6): 1291-1297 (doi: 10.1016/j.sjbs.2019.05.004).

19. Wang T., Liang Y., Wu M.B., Chen Z.J., Lin J., Yang L.R. Natural products from Bacillus subtilis with antimicrobial properties. Chinese Journal of Chemical Engineering, 2015, 23(4): 744-754 (doi: 10.1016/j.cjche.2014.05.020).

20. Petrovskii A.S., Karakotov S.D. Zashchita i karantin rastenii, 2017, 2: 14-18 (in Russ.).

21. Leonov N.N., Sokirko V.P. Trudy Kub GAU, 2015, 56: 125-131 (in Russ.).

22. Mishchenko I.G. Plodovodstvo i yagodovodstvo Rossii, 2019, 59: 239-243 (doi: 10.31676/2073-49482019-59-239-243). (in Russ.)

23. Dospekhov B.A. Metodika polevogo opyta (s osnovami statisticheskoi obrabotki rezul'tatov issledovanii [Field experiment methodology (with the basics of statistical processing of research results]. Moscow, 2012 (in Russ.).

24. Amin N. Teaching of biopesticide development as a technoprenuership opportunity in plant protection. Journal of Biology, Agriculture and Healthcare, 2013, 3(6): 2224-3208.

25. Abbott W.S. A method of computing the effectiveness of an insecticide. Journal of Economical Entomology, 1925, 18: 265-267.

26. De Sa J.P.M. Applied statistics using SPSS, Statistica, MatLab and R. Springer Science \& Business Media, 2007.

27. Anisimov V.I., Bityukov N.A. Fizicheskaya geografiya goroda-kurorta Sochi. Monografiya [Physical geography of the resort city of Sochi. Monograph]. Sochi, 2008 (in Russ.).

28. Pal K.K., McSpadden Gardener B. Biological control of plant pathogens. The Plant Health Instructor, 2006 (2): 1117-1142 (doi: 10.1094/PHI-A-2006-1117-02).

29. Harman G.E. Multifunctional fungal plant symbionts: new tools to enhance plant growth and productivity. New Phytologist, 2011, 189(3): 647-649 (doi: 10.1111/j.1469-8137.2010.03614.x). 